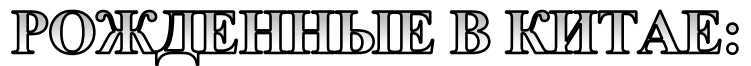

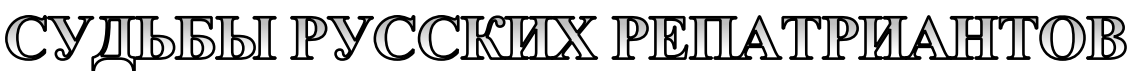

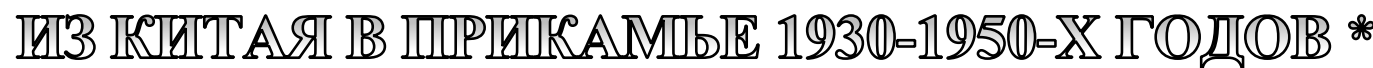

М.С. Каменских, Пермский федеральный исследовательский центр УрО РАН

В статье сделана попытка реконструировать и проанализировать особенности быта и адаптации русских, приехавших из китайской эмиграции в Прикамье 1940-1950-х годов. В основу исследования положены архивные документы, мемуары и полевые материалы автора, которые впервые вводятся в научный оборот.

Особый интерес представляет процесс адаптации репатриантов в условиях послевоенного СССР, элементы традиционной культуры дореволюционной России, которые репатрианты инкорпорировали в повседневный быт.

Ключевые слова: "русский Харбин», репатрианты, репрессии, национальная политика.

Если говорить о различных локальных группах русских в пространстве Пермского края [15, с. 57-60], необходимо признать, что совершенно особое место в этом ряду принадлежит т.н. «русским харбинцам» - эмигрантам и бывшим подданным Российской империи, которые после 1918 года оказались на территории современного Китая.

Численность русского населения в Китае в 1920-1930-е годы составляла несколько сот тысяч человек [12, с. 439], большая часть из которых разместилась в двух городах - Харбине и Шанхае. Среди них были не только представители «белого движения» и примкнувшие к ним представители творческой интеллигенции, но и крестьяне, и технические специалисты, получившие земельные наделы или работавшие на территории Китайско-Восточной Железной дороги (КВЖД) еще в досоветский период. Живя в Китае, русские создали сильную диаспору с собственными социальными

институтами, позволявшими сохранять и воспроизводить свою культуру. Диаспора не только играла заметную роль в экономике отдельных районов Китая, но и издавала газеты, организовывала тематические мероприятия, связанные с русской культурой. Известно, например, что на деньги русских эмигрантов в 1937 году в Шанхае был установлен памятник А.С. Пушкину к столетию со дня смерти поэта [5]. История этого сообщества могла сложиться по-разному, но в силу исторических причин к середине 1950-х годов практически все русское население Китая вернулось в СССР либо переехало на постоянное жительство в другие страны.

Если обратиться к историографии вопроса, можно отметить, что судьбы «русских харбинцев» активно изучались историками. Однако внимание исследователей, как правило, было обращено к периоду их жизни в Китае, в то время как их возвращение и адаптация в СССР прак-

* Статья публикуется в рамках реализации гранта РНФ № 19-18-00117 «Традиционная культура русских в зонах активных межэтнических контактов Урала и Поволжья». 
тически не нашли отражения в историографии. Исключение могут составить работы уральского историка С.В. Смирнова (больше всего «харбинцев» оказалось именно на Урале и особенно в Свердловской области), посвятившего ряд научных трудов истории общественного движения «русских харбинцев» Урала [14]. В одной из своих работ он, в частности, отмечает, что в отечественной и зарубежной историографии «почти нет исследований, посвященных проблемам социально-культурной адаптации российских репатриантов из стран эмигрантского рассеяния к советской среде» [14, с. 479].

Британский исследователь Л. Манчестер, посвятившая теме русских репатриантов из Китая ряд научных статей, также пишет, что изучение истории «русских харбинцев» после их возвращения представляется довольно проблематичным, поскольку они не были учтены никакой статистикой, их сложно было отследить в материалах переписей населения («officially, they did not exist»), советское правительство также не уделяло им достаточно внимания через официальные программы. Однако по, ее подсчетам, в 1940-1950-е годы в СССР въехало не менее 100 тыс. человек [1, с. 353]. Прикамье, являвшееся в 1930-1950-е годы одним из динамично развивавшихся научно-промышленных центров страны, также стало местом притяжения «русских харбинцев».

Данная статья посвящена реконструкции быта и адаптации русского населения Китая, вернувшегося в СССР в 1930-1950-е годы. Особый интерес для автора представляют особенности инкорпорации русской культуры Китая в социально-культурном пространстве СССР 1950-х годов. Территориальные рамки охватывают регион Прикамья. Основой публикации послужили биографии людей, родившихся в Китае в 1920-е годы и приехавших на Урал в послевоенный период. Источником исследования послужили опубликованные мемуары репатриантов и их потомков, полевые материалы автора, архивные документы.

Следует отметить, что в рамках процесса репатриации из Китая можно выде- лить несколько волн реэмиграции русского населения, каждая из которых имеет свои особенности. Первая волна имела место в конце 1920-х годов, когда территория КВЖД стала зоной постоянных конфликтов и многие бывшие подданные Российской империи захотели вернуться на родину. К ним примкнули и те, то не смог обустроиться на новом месте и не выступал против советской власти.

Однако практически все репатрианты, вернувшиеся в СССР до 1940 года, стали жертвами репрессий. Об этом, например, свидетельствует следующий факт, выявленный в протоколах допросов периода реабилитации жертв сталинских репрессий 1950-х годов по Молотовской области. Один из следователей НКВД, Н.П. Голдобеев, сообщил на допросе: «На основании директивы по инобазе Мозжерин (Мозжерин Ф.П. - начальник особой дивизии НКВД по г. Перми - M.C.) требовал ареста всех, предупреждая, что за каждого оставшегося харбинца, корейца или поляка будет отвечать тот, на чьей территории это будет обнаружено» [6, с. 55].

Таким образом, выходцы из Китая были одной из тех категорий, которые в первую очередь подлежали арестам в ходе репрессий 1930-х годов. В фондах Пермского государственного архива социально-политической истории сохранились дела 135 человек, вернувшихся из Китая и подвергнутых репрессиям в 1930-е годы, причем у 17 из них местом рождения уже был обозначен Харбин. Самые известные из арестованных - потомственные дворяне и офицеры царской армии - Б.А. Остроградский и М.Г. Торновский. Большинство из арестованных в этот период получили лагерные сроки свыше 10 лет [7]. Эти мигранты, возвращавшиеся в СССР в 1930-е годы, делали это практически по собственной инициативе, не имея возможности оставаться на территории КВЖД.

Большая часть эмигрантов в тот период осталась жить в Китае и сохраняла традиции дореволюционной России. В Шанхае и Харбине русским удалось построить практически закрытые для внешнего мира социумы, жившие по своим внутренним традициям и правилам. Причем к концу 
1940-х годов выросло целое поколение, считавшее себя русскими, но никогда не бывавшее на исторической родине. Живя в чужой стране, они воспитывались в традициях России досоветского времени - страны, которой тогда уже не существовало.

Опрошенные в ходе интервью респонденты из своих детских воспоминаний воспроизводят религиозные праздники, общение только на русском и с русскими. Китайская культура и общение с китайцами практически не отражены в воспоминаниях. «Весь уклад жизни этого мира, весь круг общения и интересов его обитателей был сугубо русским и характеризовался соблюдением привычных традиций и обычаев, религиозных праздников и обрядов, склонностью к политическим спорам и бытовым дрязгам», - писал в своих мемуарах Юрий Сильницкий [13, с. 8]. Родившаяся во французской части Шанхая Информант 2 вспоминает, что «все церковные праздники обязательно соблюдали, про елку на новый год я узнала только здесь, елку всегда ставили на Рождество. Причем китайцы делали нам еe из тростника, живую ель я увидела только в России» [9].

Вдали от родины родители старались дать своим детям классическое европейское образование и отдавали их в европейские школы, которые были открыты для русских эмигрантов при духовных учреждениях разных стран. Информант 4 закончила французскую школу Ecole Remi [10]. Георгий Сильницкий в Китае закончил также Ecole Remi и английскую Shanghai British school [13, c. 21, 33]. Информант 1 выучила английский и немецкий языки в Holy Ghost school города Циндао [8]. Дочь белого генерала Ксения Веселухина прибыла в Пермь уже являясь выпускницей университета Saint Jones в Шанхае [4]. Художник Константин Данилевский оказался в Перми будучи выпускником Пенсильванской академии художеств [2], а его сын окончил Колледж св. Патрика в Шанхае. Знание иностранных языков на тот момент оказалось очень востребованным в СССР.

В большинстве своем молодое поколение симпатизировало СССР, поскольку получало информацию о достижениях этой страны из официальных пропагандистских источников. Настроение этого поколения можно передать словами одного из эмигрантов И.И. Серебренникова: «Спрашивается, почему эти интернационалисты, всякий международный сброд живут в России, а ты, русский, должен заканчивать свои дни в каком-то чужом Китае; жить среди народа, с которым за тринадцать лет жизни здесь не имеешь, не можешь найти ничего общего. Что за нелепица?!!!» [3, с. 360].

Интересно проследить представления «харбинцев» о своей родине до репатриации. Так, Информант 3 в интервью рассказал, что его отец еще в юношестве с друзьями пытался нелегально пересечь советско-китайскую границу, чтоб попасть в СССР и вступить в ряды Красной Армии [10]. Симпатизируя СССР, молодежь создавала организации, в названии которых было слово «советский». Георгий Сильницкий, например, состоял «Советском спортивном клубе» [13, с. 31].

Отметим, что многие из их родителей позитивно воспринимали Советский Союз и его лидеров, несмотря на идеологические разногласия. Вот как вспоминала своих родителей Информант 1: «Мама Ульяна тосковала об родине, она обожала Сталина, всех руководителей Молотова, Сталина. Даже заставляла нас учить советские песни, гимн и интернационал. Дома висел портрет Сталина. В годы войны она отправляла посылки с продуктами в СССР. Нас воспитали в духе преданности и любви к той стране, в которой мы ни разу не были, но которую очень любим» [8]. Схожие воспоминания и у других респондентов. «Папа любил Советский Союз, любил Сталина и очень тосковал по родине», отметила в интервью Информант 4 [11].

Когда после 1945 года СССР и Китай договорились о статусе репатриантов, русскому населению Китая было предложено вернуться на родину, при этом инициатива на этот раз исходила от советского правительства. Все опрошенные указывали, что посольство СССР в Китае активно участвовало в процессе организации репатриации. На период конца 
1946 года - начала 1947 годов пришелся самый массовый выезд русских из Китая. Особого внимания заслуживает анализ мотивов переезда. В памяти практически всех респондентов и привлеченных к исследованию мемуарах значительное место уделяется этому эпизоду.

Судя по источникам, эмигрантское сообщество по-разному восприняло возможность вернуться на родину. Юрий Сильницкий в мемуарах отмечает, что эта возможность расколола эмигрантское сообщество. Не принявшие советскую власть покинули Китай и переехали в страны Запада или Латинской Америки, значительная часть осталась жить в Китае. Как правило, это были бизнесмены, имевшие деловые связи и собственность. А представители интеллигенции и потомки жителей территории КВЖД в большинстве решили (или были вынуждены) вернуться. Судя по полевым материалам и мемуарам, основным мотивом для переезда стал патриотизм.

Вот как описывает эту ситуацию Юрий Сильницкий: «Америка или Россия? Перед нашей семьей встал вопрос: Советский Союз или Америка? На семейном совете родители заявили, что поскольку речь идет обо всем моем будущем, окончательное решение за мной. Я до сих пор с удивлением вспоминаю, насколько просто и естественно, как бы сам собой, ответ мгновенно сформировался в моем сознании... я, не задумываясь, сказал: «Хочу в Россию» [13 с. 35]. Мама Информанта 2 изначально приняла решение поехать в Австралию, где у нее был жених. В эту страну даже были отправлены все вещи. Но в последний день они с сестрой решили, что их дети русские и должны расти в России, поэтому нужно ехать в СССР [9]. «В Россию переехали из-за патриотизма деда Михаила, - вспомнила Информант 4. - Он очень грустил по России, находясь в Китае, хотя была возможность уехать в Америку» [11]. У художника Константина Данилевского младшие брат и сестра уехали в Австралию, а он решил поехать в СССР [10].

Таким образом, оказавшиеся в 1920-е годы Китае русские сумели сохранить привычный уклад жизни и вырастить целое поколение. При этом многие из них ощущали ностальгию и даже симпатизировали СССР. В этом духе они воспитывали своих детей. Когда возникла возможность для безопасного возвращения на родину, значительная часть мигрантов решила ею воспользоваться, в том числе для того, чтоб они вернулись на историческую родину, даже в худшие для жизни условия.

Возвращаться в СССР было предложено не всем. По словам Информанта 1, представители советского правительства обещали советское гражданство только тем, кто сначала отправит на родину детей. Только отправив детей в СССР в 1946 году, ее родители смогли получить советские паспорта в 1947 году. Всего, по ее воспоминаниям, в августе 1946 года в СССР было отправлено 5 эшелонов т.н. «детских рейсов» с детьми в возрасте от 3 до 15 лет. Часть мигрантов оставалась в Китае до начала 1950-х годов, когда началась китайская «культурная революция» и последние из эмигрантов вынуждены были также уезжать, чтоб спастись от преследований местных властей. С этой волной, например, приехала в Пермь Информант 2.

Возвращение на родину «русские харбинцы» первоначально воспринимали как очень важное, исторически значимое событие. «Мы все с нетерпением ждали первой встречи с родной незнакомой землей и ее обитателями, рисовавшимися нам в нашем воображении людьми какой-то особой породы, живущими отличными от наших, возвышенными интересами, связанными с воспоминаниями о великой войне и о своем недавнем ратном подвиге», - пишет Георгий Сильницкий [13, с. 38]. Судя по воспоминаниям, репатриантам предлагали для жительства местности в восточной части России (крайней западной точкой была Молотовская область), но все мечтали вернуться поближе к столицам, поэтому наибольшее количество репатриантов добрались до Урала. Массовый заезд харбинцев в Прикамье пришелся на конец 1947 - начало1948 года.

Практически во всех интервью отражены воспоминания о денежной реформе и выборах в Верховный совет, кото- 
рые пришлись на этот период. «Нам предложили для поселения ряд сибирских городов от Кемерово до Молотова (как тогда называлась Пермь). Я тотчас вспомнил пушкинское «от Перми до Тавриды» и поэтому охотно поддержал отца, когда он предложил выбрать этот город как наиболее западный в предложенном списке» [13. с. 39]. Родители Информанта 4 планировали остановиться в Свердловске, но из-за сложностей с извлечением багажа решили ехать до конечной остановки - Соликамска. Родители Информанта 1 выбрали Урал, поскольку отец был родом из этих мест. Но для большинства приезжающих Молотов был просто точкой на карте - городом, о котором они ничего не знали.

К концу 1940-х годов в Молотове и Соликамске проживало уже несколько десятков семей - выходцев из Китая. По воспоминаниям респондентов реконструируются следующие фамилии: Окушенки, Сильницкие, Данилевские, Грековы, Шутовы, Юрьевы, Ознобихины, Жирновы, Литвяки, Гизатуллины, Хорошавины, Шмигели и др.

Первые впечатления после приезда как правило, были непростыми. Они четко отражены в воспоминаниях всех респондентов. С.В. Смирнов пишет, что «знакомство с действительностью послевоенного СССР практически для всех было шоком» [14, с. 482]. После пересечения границы на станции Отпор всех репатриантов из комфортабельных вагонов пересаживали в необустроенные теплушки. Информант 1 вспоминает, как на границе их провели через колонну вооруженных красноармейцев.

Информант 2 помнила, что даже в теплушках женщины были в радостном настроении, все надевали праздничные наряды. Поезд привез их в один из овцесовхозов Новосибирской области. «Когда я увидела деревенских детей, бритых, грязных, и сравнила их со своим праздничным нарядом, я испытала шок» [9]. Информант 4 так описала этот момент: «Я помню, как в первое время после приезда мама постоянно плакала. Условия были не сравнить с теми, что были в Китае.
Отец все время говорил, что это временно и постепенно ситуация наладится» [11]. Информант 1 отметила, что первое время без родителей им пришлось жить в интернате для сирот в Иркутске. Условия жизни, питания были неожиданно тяжелыми. А приезжая в различные города, они не получали никакой материальной поддержки, даже были обманываемы.

Детям репатриантов было сложно адаптироваться в советской школе. Несмотря на то, что они считали себя русскими, у многих возникли проблемы с элементарной коммуникацией на родном языке. Владея двумя или тремя иностранными языками, репатрианты второго поколения не очень хорошо владели родным русским. Вот как описал эту проблему Георгий Сильницкий: «Наименьшие трудности я испытывал с математикой и русской литературой, наибольшие - с русским письменным языком, со многими правилами которого я только сейчас впервые познакомился» [13, с. 47]. «Сложности в языке у меня были, - вспомнила Информант 2. - Особенно в разности слов. Слово «магазин», например, я не слышала, только «лавка». И таких примеров много» [9]. Сын художника Константина Данилевского Михаил вообще плохо говорил по-русски, когда приехал. Языковая адаптация растянулась у него на несколько лет [10]. Манера общения также была непривычной. Все интервьюируемые отметили, что не слышали до переезда в повседневной речи русского мата. Но по приезду в СССР сталкивались с ним постоянно. Мать Информанта 2, когда услышала разговор двух работников на станции во время переезда, искренне подумала, что они иностранцы из какой-то близкой славянской страны [9].

Репатрианты 1940-1950-х годов уже не подвергались репрессиям, хотя осторожное отношение к себе чувствовали. По их воспоминаниям, происхождение было фактором, влияющим на карьеру. Информанту 1 в Москве предлагали поменять место рождения в паспорте, чтоб «избежать проблем». В интервью она вспомнила, как учитель в школе неприязненно относилась к ним, говоря «зачем Вы сюда 
вообще приехали» [8]. Отца Георгия Сильницкого в 1950-е годы арестовали по 58 статье, а сам он, сказав на комсомольском собрании, что он дворянин по происхождению, почувствовал резкое ухудшение отношения к себе со стороны сверстников [13, с. 62]. Информанту 2 мама с детства говорила, чтоб она «не распространялась о своем происхождении» [9].

В первое время после прибытия семьи репатриантов сталкивались с серьезными материальными трудностями. Источником дохода для большинства была продажа вещей, с которыми они приехали из Китая. Но со временем они находили работу с достойным заработком. Квалифицированные инженеры КВЖД оказались очень востребованы в условиях послевоенного СССР с его дефицитом рабочих рук. Мать Информанта 2, имея навыки маникюра, быстро стала востребованным специалистом у жен местной элиты [9]. Немало выходцев из Китая работали в местных оркестрах, а также в Пермском театре оперы и балета.

Практически все из респондентов указали, что они или их родители занимались как частными уроками иностранных языков, так и устраивались преподавателями. Георгий Сильницкий в своих мемуарах писал, что после вуза работал преподавателем английского языка и даже был приглашен на работу в г. Нытву, чтоб учить ему рабочих $[13$, с. 33$]$. Константин Данилевский после того, как его документы об образовании не были приняты, стал трудиться переводчиком с английского и французского языков на заводе Пермнефтеоргсинтез, давал частные уроки английского языка [2]. Е.Д. Игощина и К.В. Веселухина стояли у истоков пермской школы английского языка. Уроженка Шанхая и выпускница университета Saint Jones Ксения Владимировна Веселухина с 1964 по 1972 год руководила в Пермском университете кафедрой романо-германских языков, с 1972 по 1982 годы - кафедрой английской филологии, а с 1972 по 1990 возглавляла факультет повышения квалификации. Фактически при ее участии была создана пермская школа английского языка [4]. В повседневной жизни «русские харбинцы» старались поддерживать связи друг с другом и отчасти воспроизводили привычный для себя быт. Информант 2 вспомнила, что у них дома постоянно были гости - другие выходцы из Китая. Они курили папиросы, играли в маджонг, обсуждали новости мировой политики, сочувствовали Китаю и не любили японцев. Информант 3 отметил, что его родители привезли из Китая культуру варить и пить каждый день кофе, хотя в первое время в условиях г. Молотова найти его было сложно [10]. Таким образом, репатрианты из Китая, несмотря на сложности, смогли адаптироваться в местной системе трудовых отношений и стать успешными.

Таким образом, попадая в СССР, выходцы из Китая, родившиеся там, безусловно, являлись носителями русской культуры. Но при этом она существенно отличалась от той, что сформировалась в СССР за 1920-1940-е годы. Не все русские переехали обратно в СССР в 1940-1950-е годы, но те, кто вернулся, делали это по мотивам патриотизма и сознательно соглашались на худшие для жизни условия. Процесс адаптации был непростым и возвращенцы первой волны, скорее всего, не смогли полностью интегрироваться в местное сообщество, в том числе по причине настороженного отношения к ним со стороны официальной власти и местного населения, трудностями, связанными с их биографией.

Между тем они и их дети по прошествии времени смогли оказаться полезными в сложившейся к началу 1950-х годов хозяйственной системе. Навыки межкультурных коммуникаций, полученные в Китае, уникальные профессии, которых не было в СССР, позволили им успешно интегрироваться в систему трудовых отношений и даже внести вклад в развитие региона (как это было с английским языком). Сегодня потомки репатриантов в третьем и четвертом поколении продолжают жить в Пермском крае, они уже полностью адаптировались в местном сообществе, а «китайское происхождение» предков хранится только на уровне семейных преданий. 
Библиографический список

1. Manchester L. Repatriation to a Totalitarian Homeland: The Ambiguous Alterity of Russian Repatriates from China to the USSR // Diaspora: a journal of transnational studies. - 2013. - № 16:3. - P. 353-386.

2. Данилевский К.П. [Электронный ресурс]: Искусство и архитектура русского зарубежья. URL.: https:/artrz.ru/authors/1805350198/1804869082.html (дата обращения: 08.09.2020).

3. Китай и русская эмиграция в дневниках И.И. и А.Н. Серебренниковых. В 5 т. - М.: РОССПЭН, 2006. - Т. 1: «Пока же мы счастливы тем, что ничто не угрожает нам» (1919-1934). - 448 с.

4. Веселухина К.B. [Электронный ресурс]: ПГНИУ. URL.: http://www.psu.ru/fakultety/fakultetsovremennykh-inostrannykh-yazykov-i-literatur/kafedry/kafedra-anglijskoj-filologii/kvveselukhina (дата обращения: 15.09.2020).

5. Памятник Пушкину в Шанхае [Электронный ресурс]: Китайский акцент. URL.: http://kitayskiyakcent.ru/puteshestvuem/shanghai/pamyatnik-pushkinu-v-shanhae\#: :text (Дата обращения: 20.08.2020).

6. Пермский государственный архив социально-политической истории (ПермГАСПИ). Ф. 643/2. Оп. 1. Д. 30974.

7. Пермь - Харбин - Гулаг. Коллекция дел о репатриантах из Китая в Пермской области [Электронный ресурс]: ПермГАСПИ. URL.: https://www.permgaspi.ru/publikatsii/stati/perm-harbingulag-kollektsiya-del-o-repatriantah-iz-kitaya-v-permskoj-oblasti.html (дата обращения: 10.09.2020).

8. Полевые материалы автора (ПМА). Информант 1, Ж., 09.05.1934 г.р. Пермь, 2019.

9. ПМА. Информант 2, Ж., 16.06.1946 г.р. Пермь, 2019.

10. ПМА. Информант 3, М., 08.01.1961 г.р. Пермь, 2019

11. ПМА. Информант 4, Ж. 09.08.1937 г.р. Пермь, 2020.

12. Полян. П. Эмиграция: кто и когда в XX веке покидал Россию // Россия и ее регионы в XX веке: территория - расселение - миграции / под ред. О. Глезер и П. Поляна. - М.: ОГИ, 2005 с. 493-519.

13. Сильницкий Г.Г. Осмысление прошлого (четыре круга спирали одной жизни). Смоленск: Изд-во СмолГУ, 2017. - 188 с.

14. Смирнов С.В. «Русская Атлантида»: воспоминания русских репатриантов из Китая и проблема конструирования диаспорической идентичности // Новое литературное обозрение. - 2014. - № 3. C. $478-486$.

15. Черных A.B., Каменских М.С. Белавин А.М. Этническая история Пермского края // Народы Пермского края: этническая история и современное этнокультурное развитие: Словарьсправочник. - СПб.: Маматов, 2014. - С. 39-83.

\title{
BORN IN CHINA: THE FATE OF RUSSIAN REPATRIATES FROM CHINA TO PERM REGION IN THE 1930s-1950s
}

\author{
M.S. Kamenskikh \\ Perm Federal Research Center UB RAS
}

In the paper, an attempt is made to reconstruct and analyze the features of the way of life and adaptation of Russians having moved to Perm region from Chinese emigration in the 1930s-1950s. For the first time the archival documents, memoirs and field research materials, studied by the author, are introduced into scientific circulation.

Of special interest is the adaptation process of the repatriates to the USSR after the World War II, as well as the elements of the traditional culture of pre-revolutionary Russia that were incorporated in their everyday life.

Keywords: Russian Harbin, repatriates, repressions, national policy.

\section{Сведения об авторе}

Каменских Михаил Сергеевич, кандидат исторических наук, старший научный сотрудник отдела истории, археологии и этнографии, Пермский федеральный исследовательский центр УрО РАН (ПФИЦ УрО РАН), 614900, г. Пермь, ул. Ленина, 13А; e-mail: pomidorrr@mail.ru 